\title{
PREZENTAGJE
}

\section{Polityka a wychowanie. Toruński ośrodek badań w dziedzinie historii wychowania}

(Zaklad Historii Wychowania i Myśli Spolecznej Instytutu Pedagogiki UMK)

Badania naukowe w zakresie historii wychowania prowadzone w Uniwersytecie Mikołaja Kopernika w Toruniu mają już wieloletnią tradycję. Z utworzoną w 1945 r. przez prof. dra hab. Kazimierza Sośnickiego Katedrą Pedagogiki UMK, przemianowana siedem lat później na Katedrę Pedagogiki i Psychologii, już w latach czterdziestych związani byli m.in. prof. dr hab. Stefan Woloszyn, prof. dr hab. Bolesław Pleśniarski, póżniejszy wieloletni kierownik wspomnianej Katedry, dyrektor Instytutu Pedagogiki i Psychologii UMK w latach 1976-1978, a także - jednocześnie - kierownik Zakładu Historii i Teorii Wychowania, a w okresie póżniejszym prof. dr hab. Jerzy Danielewicz oraz prof. dr hab. Teresa Wróblewska. W latach 1991 - 1996 pracami zreorganizowanego pod względem personalnym oraz profilu badań Zakładu Historii Wychowania i Myśli Spolecznej Instytutu Pedagogiki UMK kierowal prof. dr hab. Andrzej Wojtas. Od r. 1996 funkcje jego kierownika sprawuje prof. dr hab. Witold Wojdyło, obok którego niewielki zespół historyków wychowania wspóltworzą dr Michal Strzelecki i mgr Jarosław Góralski.

Działalność dydaktyczna Zakładu Historii Wychowania i Myśli Społecznej związana jest z funkcjonowaniem Instytutu Pedagogiki UMK $\mathrm{i}$ istniejącymi $w$ nimı kierunkami studiów. W konsekwencji pracownicy Zakładu prowadza zajecia z przedmiotu „Historia wychowania" na pięcioletnich, stacjonarnych studiach magisterskich (30 godz. wykładów, 60 godz. ćwiczeń, II rok), trzyletnich, stacjonarnych studiach zawodowych (1 rok. 15 godz. wykładów), a także pięcioletnich i trzyletnich (dla absolwentów SN) zaocznych studiach magisterskich (I rok - 20 godz. wykładów, 20 godz. ćwiczeń). W Zakładzie prowadzone są również seminaria magisterskie, których uczestnicy przygotowują prace poświęcone różnorodnym aspektom polskiej myśli spolecznej i edukacyjnej, a także funkcjonowaniu regionalnych placówek edukacyjno-wychowawczych w XX w.

W prowadzonych badaniach naukowych zespól toruńskich historyków wychowania, którego obecny skład personalny ustalił się dopiero w 1996 r, koncentruje się przede wszystkim na relacjach między zalożeniami ideowymi i działalnością polskich ugrupowań i stronnictw politycznych XX w, a formułowanymi przezeń koncepcjami oświatowymi i wychowawczymi, traktując tym samym wychowanie jako istotny element polityki oraz składnik transformacji spotecznych. Ranga wspomniane problematyki wynika $z$ faktu, iż wszystkie polskie ugrupowania polityczne dążyły do uzyskania wplywu na postepowanie i zachowanie jednostek, rodzin, jak i szerszych zbiorowości, rozbudzenia wiary w głoszone idealy, a w konsekwencji do aktywizacji spoleczeństwa.

Powyższy profil zainteresowań pracowników Zakładu Historii Wychowania i Myśli Spolecznej określony zostal w latach 1992 - 1994 w trakcie realizacji projektu badawczego, finansowanego przez Komitet Badań Naukowych, którego kierownikiem był prof. dr 
hab. Andrzej Wojtas. Efektem prowadzonych wówczas badań była praca zbiorowa zatytułowana Polityka a wychowanie'.

Kontynuując wspomniane badania prof. dr hab. Witold Wojdyło koncentruje się głównie na problematyce wychowania narodowego, a zwłaszcza koncepcjach oświatowo-wychowawczych obozu narodowo-demokratycznego w okresie II Rzeczypospolitej oraz II wojny światowej ${ }^{2}$.

Dr Michal Strzelecki podejmuje natomiast w swych publikacjach zagadnienia związane z rolą wychowania i koncepcjami ksztaltowania społeczeństwa obywatelskiego w myśli politycznej ruchu ludowego, a także legalnych środowisk opozycyjnych po II wojnie światowej ${ }^{3}$.

Zaprezentowana powyżej problematyka stanowi również przedmiot zainteresowania i poszukiwań badawczych uczestników prowadzonego od 1995 r. przez prof. dra hab. W. Wojdyłe seminarium doktoranckiego.

Relacje pomiędzy polityka a wychowaniem stanowiły również przedmiot rozważań uczestników interdyscyplinarnej konferencji naukowej „Wychowanie a polityka. Tradycje i współczesnośc", zorganizowanej przez pracowników Zakładu Historii Wychowania i Myśli Społecznej Instytutu Pedagogiki UMK w dniach 7-8 listopada 1996 r., w której obok historyków wychowania udział wzięli również historycy myśli politycznej, filozofowie, pedagogowie, socjologowie oraz historycy literatury, reprezentujący różne krajowe środowiska akademickie, a także historycy wychowania z Uniwersytetu w Oldenburgu, z którymi toruńscy badacze utrzymuja stałe kontakty naukowe.

Zamierzeniem organizatorów konferencji jest nadanie jej charakteru cyklicznego $\mathrm{i}$ tym samym wpisanie na stałe do kalendarza spotkan przedstawicieli dyscyplin naukowych podejmujących wspomnianą problematykę.

Charakteryzując działalność naukowa toruńskiego Zakładu Historii Wychowania i Myśli Społecznej należy również podkreślić jego kontakty naukowe $\mathrm{z}$ Instytutem Historii i Archiwistyki, Instytutem Socjologii oraz Instytutem Filozofii UMK, a także z Pomorskim Archiwum Armii Krajowej, którego współzałożycielką jest legendarna „cichociemna”, prof. $\mathrm{dr}$ hab. Elżbieta Zawacka.
Na uwage zasługuje także współpraca z Wydawnictwem Adam Marszałek, wydawca ogólnopolskiego, interdyscyplinamego kwartalnika „Kultura i Edukacja”, na łamach którego publikowane sa m.in. artukuły z zakresu historii wychowania i myśli społecznej przedstawicieli różnych krajowych ośrodków naukowych.

Reasumując, należy podkreślić, iż głównym celem działalności naukowej niewielkiego grona pracowników Zakładu Historii Wychowania i Myśli Społecznej Instytutu Pedagogiki UMK jest uczynienie $\mathrm{z}$ Torunia ważnego ośrodka w zakresie badań nad historią wychowania XX wieku, a zwłaszcza relacjami między polityką a szeroko rozumianą problematyka oświatowo-wychowawczą.

\section{Michal Strzelecki}

1 Zob. Polityka a wychowanie. Szkic z dziejów wychowania spolecznego w Polsce, red. A. Wojtas, Wydawnictwo Adam Marszakek, Toruń 1993.

${ }^{2}$ Zob. W. Wojdylo, Koncepcje spoleczno-polityczne Stanislawa Grabskiego, Wydawnictwo UMK, Toruń 1994; idem, Wychowanie jako forma dzialania politycznego w koncepcjach ruchu narodowego przed I wojng swiatowa, w: U tródel polskiej nowoczesnej myśli politycznej w $X I X$ i $X X$ wieku, red. M. Baumgart, J. Jekiel, Szczecin 1996, s. 85-100.

${ }^{3}$ Zob. m.in. M. Strzelecki, Dzialalnośc opozycji parlamentarnej w Krajowej Radzie Narodowej i Sejmie Ustawodawczym (VI 1945 - X 1947), Wydawnictwo Adam Marszałek, Toruń 1996; idem, Walka o realizację idei niepodleglosci Polski w ruchu chlopskim w zabo rze pruskim, "Rocznik Historyczny Muzeum Historii Polskiego Ruchu Ludowego", nr 9: 1995 (wyd. 1996), 8. $26-35$ 